\title{
Polimorfisme gen ferroportin (FPN1) -1355 G/C sebagai faktor risiko anemia defisiensi besi pada ibu hamil
}

\section{Polymorphism of FPN1 gene promoter -1355 G/C as a risk factor of iron deficiency anemia in pregnant women}

Nor Istiqomah ${ }^{1}$, Sarah Safira Umarghanies ${ }^{2}$, Arta Farmawati², Ahmad Hamim Sadewa ${ }^{2}$, Yuliana Heri Soesilo ${ }^{3}$, Kusumadewi Eka Damayanti $^{3}$, Dono Indarto ${ }^{3}$

\begin{abstract}
Background: According to WHO data, prevalence of anemia pregnancy in Indonesia is 44.3\%, it's higher than world prevalence (41.8\%). Ferroportin (FPN1) is one of important iron exsporter for iron absorption, release, and recycle inside the body. The varian of FPN1-1355 G/C in promoter region, leads to increased of ferroportin expression and iron export, increased cellular iron needs, overexpression of soluble transferrin receptor (sTfR), decrease hemoglobin (Hb) and erythrocyte indices that manifest to iron deficiency anemia (IDA).

Objective: This research will study the frequency of FPN1-1355 G/C polymorphism as a risk factor of IDA in pregnant women in Indonesia.

Method: The research design was a case and control study. Blood samples were taken from 26 pregnant women with anemia and 48 pregnant women without anemia. FPN1-1355G/C polymorphism were determined using PCR-RFLP method. sTfR and ferritin level were measured with ELISA. Hemoglobin, erythrocyte indices, and sTfR level were compared among genotype group, then statistically analyzed using independent sample t-test and one way ANOVA. Bivariat analysis of Pearson test was conducted to analyze correlation between level of blood Hb and ferritin in pregnant women $(p<0.05)$.

Results: FPN1-1355 G/C polymorphism with frequency in pregnant women with IDA and in pregnant women with anemia non IDA were $100 \%$ and $95.2 \%$, respectively ( $p=0.710 ; 0 R=1.600 ; 95 \% \mathrm{Cl}$ : 0.296-8.653). The mean of $\mathrm{Hb}$ level and erythrocyte indices in subjects carrying $C$ allele were lower than subjects carrying only $\mathrm{G}$ allele although $\mathrm{Hb}$ level is not significantly different ( $p>0.05)$. The sTfR and hepcidin level in subjects carrying $C$ allele were higher than subjects carrying only $G$ allele $(p<0.05)$.

Conclusion: In this study the FPN1 gene promoter -1355 G/C polymorphism was not a risk factor for anemia, but it was a risk factor for iron deficiency anemia in pregnant women.
\end{abstract}

KEY WORDS: polymorphism of ferroportin (FPN1) -1355 G/C, iron deficiency anemia (IDA), soluble transferin receptor (sTfR), ferritin

\begin{abstract}
ABSTRAK
Latar belakang: Berdasarkan laporan WHO, prevalensi anemia kehamilan di Indonesia sebesar 44,3\%, lebih tinggi daripada angka prevalensi dunia (41,8\%). Kejadian paling sering pada anemia kehamilan adalah anemia defisiensi besi (ADB). Ferroportin (FPN1) merupakan protein eksporter besi yang penting untuk absorpsi besi dan pelepasan besi sebagai bahan pembuatan kembali eritrosit dalam tubuh. Variasi regio promoter FPN1-1355 G/C menyebabkan peningkatan ekspresi ferroportin dan ekspor besi sehingga kebutuhan besi seluler meningkat, sTfR over ekspresi sedangkan ferritin serum, hemoglobin $(\mathrm{Hb})$, dan indeks eritrosit menurun, yang menunjukkan terjadinya $A D B$.

Tujuan: Mempelajari frekuensi polimorfisme gen FPN1-1355 G/C dan kemungkinannya sebagai faktor risiko ADB pada ibu hamil di Indonesia.

Metode: Jenis penelitian ini analitik kategorik case-control. Sampel darah diambil dari 26 ibu hamil anemia dan 48 ibu hamil tidak anemia. Pemeriksaan polimorfisme FPN1-1355 G/C menggunakan metode PCR-RFLP. Kadar sTfR dan ferritin diukur dengan metode ELISA. Kadar Hb, indeks eritrosit, dan sTfR kemudian dibandingkan antar kelompok genotip dengan independent sample t-test dan one way ANOVA. Analisis bivariat Pearson test digunakan untuk melihat hubungan antara kadar ferritin dengan $\mathrm{Hb}(p<0,05)$.

Hasil: Frekuensi genotip polimorfisme promoter gen FPN1-1355 G/C pada ibu hamil yang menderita ADB sebesar $100 \%$ sedangkan pada ibu hamil yang menderita anemia bukan karena defisiensi besi sebesar 95,2\% ( $p=0,710$; OR=1,600; 95\% Cl: 0,296-8,653). Rerata kadar $\mathrm{Hb}$ dan indeks eritrosit subjek yang membawa alel C lebih rendah daripada alel $G$, meskipun kadar Hb tidak berbeda bermakna $(p>0,05)$. Rerata kadar sTfR subjek yang membawa alel C lebih tinggi daripada alel $G(p<0,05)$.
\end{abstract}

\footnotetext{
${ }^{1}$ Korespondensi: Program Studi Kesehatan Masyarakat, Fakultas Ilmu Kesehatan Universitas Pekalongan, Jl. Sriwijaya no 3, Pekalongan, e-mail: noristiqomah@gmail.com

2 Bagian Biokimia, Fakultas Kedokteran Universitas Gadjah Mada, Jl. Farmako, Sekip Utara, Yogyakarta, e-mail: a.farmawati@gmail.com

${ }^{3}$ Fakultas Kedokteran Universitas Sebelas Maret, JI. Ir. Sutami No. 36 A Kentingan, Jebres, Surakarta 57126
} 
Simpulan: Polimorfisme promoter FPN1 -1355 G/C bukan merupakan faktor risiko terjadinya anemia pada umumnya, akan tetapi sebagai faktor risiko pada anemia defisiensi besi ibu hamil.

KATA KUNCI: polimorfisme promoter gen FPN1 -1355G/C, anemia defisiensi besi (ADB), soluble transferrin receptor (sTfR), ferritin

\section{PENDAHULUAN}

Anemia pada ibu hamil masih merupakan indikator kesehatan nasional yang mencerminkan nilai kesejahteraan sosial ekonomi masyarakat, serta berpengaruh terhadap kualitas sumber daya manusia. Anemia kehamilan sering disebut-sebut "potensial danger to mother and child" atau berpotensi membahayakan ibu dan anak. Di Indonesia, anemia kehamilan termasuk dalam kategori berat dengan prevalensi mencapai 44,3\% (1), bahkan di Provinsi Jawa Tengah sebesar $57,7 \%$. Demikian juga dengan prevalensi anemia kehamilan di Surakarta yang tergolong tinggi $(53,4 \%)$, meskipun angka cakupan pemberian suplementasi besi sudah cukup tinggi ( $80 \%$ ) (2). Fakta ini menunjukkan bahwa peningkatan angka cakupan suplementasi besi belum sejalan dengan penurunan prevalensi anemia defisiensi besi pada ibu hamil.

Defisiensi besi merupakan kondisi normal fisiologis yang terjadi pada ibu hamil, yaitu adanya penurunan konsentrasi besi dalam tubuh, baik pada penyimpanan, sirkulasi, maupun dalam bentuk ikatan dengan heme sehingga dapat menyebabkan penurunan konsentrasi eritrosit (anemia). Namun, jika kondisi tersebut dibiarkan akan mengganggu kesehatan ibu dan bayinya. Ibu hamil dengan anemia rentan terhadap infeksi, kelahiran prematur, berat badan bayi lahir rendah (BBLR), bahkan kematian prenatal. Adanya defisiensi besi menunjukkan gangguan dalam homeostasis besi (3). Salah satu protein penting untuk distribusi besi di jaringan dan mempengaruhi konsentrasi besi plasma adalah ferroportin, sebuah protein transporter yang dikode oleh gen FPN1 dan diekspresikan pada permukaan enterosit, hepatosit, dan jaringan makrofag (4). Pada ibu, anemia defisiensi besi (ADB) dapat meningkatkan proporsi kematian ibu karena perdarahan antepartum dan postpartum (5). Peningkatan faktor risiko ADB akan menyebabkan peningkatan kerentanan pula pada akibatnya.

Pada studi sebelumnya, tidak ditemukan adanya variasi atau polimorfisme gen ferroportin $\mathrm{Q} 248 \mathrm{H}$ pada populasi ibu hamil di Surakarta (6). Meskipun demikian, kegagalan absorpsi besi pada kasus ADB masih dicurigai salah satunya dipengaruhi oleh gen transporter besi tersebut, mengingat pentingnya peran ferroportin untuk homeostasis besi. Sehingga pada penelitian ini akan dikaji lebih lanjut polimorfisme gen ferroportin pada tingkat promoter, khususnya SNP -1355 G/C. Polimorfisme 5'UTR $-1355 \mathrm{C} \rightarrow \mathrm{G}$ pernah diteliti pada populasi pasien porphyria cutanea tarda (PCT) dengan frekuensi heterozigot $65 \%$ dan fenotip terjadi gangguan metabolisme besi (7). Namun, polimorfisme tersebut belum diteliti pada populasi ibu hamil yang rentan terhadap $\mathrm{ADB}$ akibat gangguan metabolisme besi. Analisis in-silico menunjukkan perubahan 5 'UTR $-1355 \mathrm{G} \rightarrow \mathrm{C}$ akan mengaktifkan faktor transkripsi FOXC1 terikat pada iron-responsive element (IRE) 5 'sehingga terjadi translasi gen FPN1 (6). Peningkatan ekspresi ferroportin menyebabkan ekspor besi berlebihan sehingga terjadi peningkatan kebutuhan besi tubuh yang ditunjukkan dengan peningkatan ekspresi soluble transferrin receptor (sTfR).

Ibu hamil secara fisiologis akan mengalami penurunan jumlah eritrosit (anemia), tetapi kondisi anemia ini belum tentu merupakan ADB. Pemberian tablet besi pada ibu hamil anemia yang bukan disebabkan oleh defisiensi besi justru akan berisiko resistensi insulin dan gangguan sindrom metabolik $(8,9)$. Oleh karena itu, pengetahuan akan pola genetik seorang ibu, khususnya varian FPN1 -1355G/C akan membantu menjelaskan apakah ibu tersebut berisiko mengalami gangguan metabolisme besi atau tidak. Koreksi penyebab ADB pada ibu hamil melalui pendekatan genetik ini diharapkan dapat dikembangkan menjadi terapi spesifik secara individual (individual therapy) sehingga dapat mengurangi angka kejadian anemia khususnya ADB pada ibu hamil serta meningkatkan kesehatan ibu dan bayi.

Pentingnya peran ferroportin untuk regulasi status besi dalam tubuh menjadi salah satu kandidat yang juga mempengaruhi kejadian anemia terutama berkaitan dengan status besi pada ibu hamil. Penelitian senada belum pernah dibuktikan pada populasi ibu hamil di Indonesia, sehingga pada penelitian ini akan dilakukan analisis hubungan polimorfisme promoter FPN1 -1355G/C terhadap kadar soluble transferrin receptor (STfR) dan ferritin sebagai indikator status besi pada ibu hamil anemia dan non anemia dengan populasi ibu hamil di Surakarta.

\section{BAHAN DAN METODE}

Penelitian ini merupakan penelitian analitik kategorik bersifat case control yang dilakukan pada bulan Mei 2012 hingga Januari 2013. Izin penelitian dan kelaikan etik diperoleh dari Komite Etik Penelitian Kesehatan dan Kedokteran (MHREC) Universitas Gadjah Mada. Subjek penelitian ini adalah ibu hamil pada tujuh (7) wilayah di bawah puskesmas yang dipilih sesuai rekomendasi Dinas Kesehatan Surakarta yang merujuk pada data insidensi anemia ibu hamil di tujuh tempat tersebut serta kemudahan dijangkau yaitu Puskesmas Banyuanyar, Gambirsari, 
Krembyongan, Ngoresan, Pucangsawit, Sangkrah, dan Sibela. Ibu hamil dari data bidan masing-masing puskesmas dikumpulkan pada saat jadwal kartu menuju sehat (KMS) dan kelas ibu di masing-masing puskesmas. Subjek dipilih berdasarkan kriteria inklusi yaitu usia ibu 18-35 tahun yang merupakan usia produktif, usia kehamilan 10-25 minggu, dan menandatangani informed consent. Usia kehamilan 10-25 minggu atau memasuki trimester 2 hingga awal trimester 3 dipilih karena secara fisiologis peningkatan kebutuhan besi ibu hamil tertinggi pada trimester kedua. Subjek dieksklusi jika secara bersamaan menderita penyakit kronis (tuberkulosis/ TBC paru, diabetes mellitus, malaria, jantung, hepatitis) atau penyakit yang mengganggu eritropoesis berdasarkan hasil angket yang diisi dan memiliki kadar hemoglobin $(\mathrm{Hb})$ di bawah $7 \mathrm{~g} / \mathrm{dL}$ (anemia berat) berdasarkan etika pengambilan darah sampel.

Besar sampel ditentukan berdasarkan rumus dengan Odds Rasio (OR) dari penelitian sebelumnya sebesar 3,64 (10); tingkat kemaknaan $\left(Z_{\alpha}\right)$ sebesar 1,96; dan kekuatan uji $\left(Z_{\beta}\right)$ sebesar 0,84 . Sampel minimal pada masing-masing kelompok sebesar 41 orang sehingga total sampel minimal sebanyak 82 orang. Tahap awal pengambilan sampel diperoleh total populasi ibu hamil yang mau diperiksa dan menandatangani informed consent sebanyak 120 ibu hamil. Namun, terdapat 46 ibu hamil tidak memenuhi syarat inklusi karena usia kehamilan di luar 10-25 minggu. Sebanyak 74 subjek yang memenuhi kriteria inklusi diukur kadar $\mathrm{Hb}$ dengan metode cyanmethemoglobin dan indeks eritrosit untuk mengelompokkan subjek. Kelompok anemia $(\mathrm{Hb}<11 \mathrm{~g} / \mathrm{dL})$ didapatkan 26 ibu hamil dan kelompok tidak anemia $(\mathrm{Hb} \geq 11 \mathrm{~g} / \mathrm{dL})$ sebanyak 48 ibu hamil, rasio yang digunakan untuk kelompok kasus : kontrol = $1: 2$.

Selanjutnya, untuk melihat hubungan yang lebih spesifik, subjek dibagi lagi menjadi kelompok ibu hamil ADB dan ibu hamil anemia bukan ADB. Diagnosis yang ditegakkan untuk ADB yaitu kadar Hb kurang dari $11 \mathrm{~g} / \mathrm{dL}$ dan indeks eritrosit di bawah normal (mean corpuscular volume / $\mathrm{MCV}<80 \mathrm{fl}$, mean corpuscular hemoglobin / $\mathrm{MCH}<26 \mathrm{pg} / \mathrm{sel}$, dan atau mean corpuscular hemoglobin concentration / $\mathrm{MCHC}<31 \%$ ) (2). Diketahui bahwa dari 26 ibu hamil anemia hanya 5 yang merupakan anemia defisiensi besi (ADB) sedangkan lainnya sebanyak $21 \mathrm{ibu}$ hamil mengalami anemia bukan ADB.

Pemeriksaan kemudian dilanjutkan pada pemeriksaan deoxyribose nucleic acid (DNA) dengan metode polymerase chain reaction-restriction fragment length polymorphism (PCR-RFLP) dan analisis serum ferritin serta sTfR dengan metode enzyme linked immunosorbent assay (ELISA) yang dilakukan di laboratorium Biokimia Fakultas Kedokteran Universitas Gadjah Mada. Peneliti dengan pengawasan teknisi laboratorium melakukan isolasi DNA genom dari sampel darah subjek menggunakan kit isolasi Promega ${ }^{\circledR}$. Selanjutnya, DNA genom diamplifikasi menggunakan kit Master Mix Go Taq Green Promega ${ }^{\circledR}$. Amplifikasi promoter
FPN1 -1355 menggunakan metode PCR dengan primer forward: 5'-GTA GAC CTT TGG GGC TCC TG-3' dan primer reverse 5'-TGG AGG GTG AGG TGA ATG AC-3' (8). Adapun kondisi PCR yang digunakan sebagai berikut: pre denaturasi pada $95^{\circ} \mathrm{C}$ (5 menit) kemudian amplifikasi PCR menggunakan 35 siklus; denaturasi pada $95^{\circ} \mathrm{C}(1$ menit); annealing pada $60^{\circ} \mathrm{C}$ (2 menit); dan ekstensi pada $72^{\circ} \mathrm{C}$ (1 menit). Selanjutnya, final ekstensi pada $72^{\circ} \mathrm{C}(10$ menit) dalam thermal cycler 9600 (Esco). Produk PCR sepanjang 288 bp kemudian dipotong dengan enzim Bfal $\left(\mathrm{MBI}\right.$ Fermentas $\left.{ }^{\circledR}\right)$. Enzim restriksi Bfal akan memotong alel C (wild type) pada ukuran $285 \mathrm{bp}$, sedangkan alel $\mathrm{G}$ berukuran 255 dan 30 bp. Hasil amplifikasi DNA dielektroforesis pada gel agarosa $2 \%$ dalam bufer TrisBoric Acid-EDTA (Tris Borate 0,045 M; ethylene diamine tetra acetic acid $0,001 \mathrm{M} \mathrm{pH} \mathrm{8,0)} \mathrm{yang} \mathrm{mengandung}$ etidium bromide dan menggunakan aparatus elektroforesis Horizontal Mini Sub DNA (Bio-Rad Lab).

Pemeriksaan kadar sTfR dikerjakan sesuai dengan metode ELISA yang tercantum pada Human sTfR Immunoassay kit DTFR1 merk Quantikine IVD ${ }^{\circledR}$. Pemeriksaan kadar ferritin dilakukan dengan metode ELISA merk DRG ${ }^{\circledR}$ Ferritin (EIA-1872). Kedua hasil ELISA tersebut dibaca dalam 15-30 menit dengan microplate reader pada panjang gelombang $450 \mathrm{~nm}$.

Data yang diperoleh dianalisis menggunakan program komputer SPSS 19 dengan tingkat kemaknaan $5 \%(p<0,05)$. Perbandingan rerata kadar $\mathrm{Hb}, \mathrm{sTfR}$, dan ferritin antar kelompok ibu hamil anemia dan tidak anemia diketahui dengan independent sample t-test bila data terdistribusi normal. Namun, apabila data tidak terdistribusi normal maka data ditransformasi terlebih dahulu. Jika tetap tidak terdistribusi normal, akan dilakukan uji MannWhitney. Perbandingan rerata $\mathrm{Hb}$, sTfR, dan ferritin antar kelompok genotip diketahui dengan melakukan uji One Way ANOVA. Frekuensi genotip dalam masing-masing kelompok kasus dan kontrol diketahui dengan analisis ChiSquare, alternatifnya uji Fisher-Exact kemudian ditentukan odds ratio-nya.

\section{HASIL}

Subjek penelitian sebanyak 74 ibu hamil yang bersedia berpartisipasi dalam penelitian ini berusia ratarata $26,5 \pm 4,6$ tahun dengan usia minimal 19 tahun dan maksimal 35 tahun. Rerata usia kehamilan 16,4 $\pm 4,2$ minggu dengan usia kehamilan minimal 10 minggu dan maksimal 25 minggu. Subjek kemudian dikelompokkan ke dalam kelompok anemia dan tidak anemia berdasarkan kadar Hb. Sebanyak 48 subjek penelitian $(61,54 \%)$ termasuk kelompok tidak anemia (kadar $\mathrm{Hb}>11 \mathrm{~g} / \mathrm{dL}$ ) dan 26 subjek $(33,33 \%)$ kelompok anemia (kadar $\mathrm{Hb}<11 \mathrm{~g} / \mathrm{dL}$ ) (Tabel 1). Subjek anemia kemudian dibagi lagi menjadi anemia defisiensi besi (ADB) dan anemia bukan karena 
Tabel 1. Karakteristik subjek kelompok anemia dan tidak anemia

\begin{tabular}{lccc}
\hline \multirow{2}{*}{ Karakteristik subjek } & \multicolumn{2}{c}{ Nilai (rerata \pm SD) } & \multirow{2}{*}{ p (CI 95\%) } \\
\cline { 2 - 3 } & Anemia (n=26) & Tidak anemia (n=48) & \\
\hline Usia ibu (tahun) & $25,923 \pm 4,454$ & $26,604 \pm 4,676$ & $0,545(-2,914 ; 1,552)^{*}$ \\
Usia kehamilan (minggu) & $18,308 \pm 4,576$ & $15,250 \pm 3,449$ & $0,002(1,175 ; 4,940)^{*}$ \\
\hline
\end{tabular}

Keterangan: *independent sample t-test; SD = standar deviasi; $\mathrm{Cl}=$ confidence interval

Tabel 2. Karakteristik subjek kelompok ADB dan bukan ADB

\begin{tabular}{|c|c|c|c|}
\hline \multirow{2}{*}{ Karakteristik subjek } & \multicolumn{2}{|c|}{ Nilai (rerata $\pm S D)$} & \multirow{2}{*}{ p (Cl 95\%) } \\
\hline & ADB $(n=5)$ & Bukan ADB $(n=21)$ & \\
\hline Usia ibu (tahun) & $23,800 \pm 3,962$ & $26,429 \pm 4,501$ & $0,243(-7,163 ; 1,906)^{\star}$ \\
\hline Usia kehamilan (minggu) & $14,600 \pm 5,727$ & $19,190 \pm 3,919$ & $0,041(-8,980 ;-0,201)^{*}$ \\
\hline Kadar $\mathrm{Hb}(\mathrm{g} / \mathrm{dL})$ & $10,200 \pm 0,579$ & $10,371 \pm 0,362$ & $0,405(-0,589 ; 0,246)^{*}$ \\
\hline Kadar MCV (fL) & $69,940 \pm 4,475$ & $88,509 \pm 4,545$ & $0,000(-23,226 ;-13,913)^{*}$ \\
\hline Kadar MCH (pg/sel) & $22,200 \pm 2,019$ & $29,386 \pm 1,910$ & $0,000(-9,166 ;-5,205)^{*}$ \\
\hline Kadar MCHC (g/dL) & $31,270 \pm 0,920$ & $33,195 \pm 1,387$ & $0,034(-2,831 ;-0,119)^{*}$ \\
\hline
\end{tabular}

Keterangan: *independent sample t-test; $\mathrm{ADB}=$ anemia defisiensi besi; $\mathrm{Hb}=$ hemoglobin; $\mathrm{MCV}=m e a n$ corpuscular volume; $\mathrm{MCH}=$ mean corpuscular hemoglobin; $\mathrm{MCHC}=$ mean corpuscular hemoglobin concentration

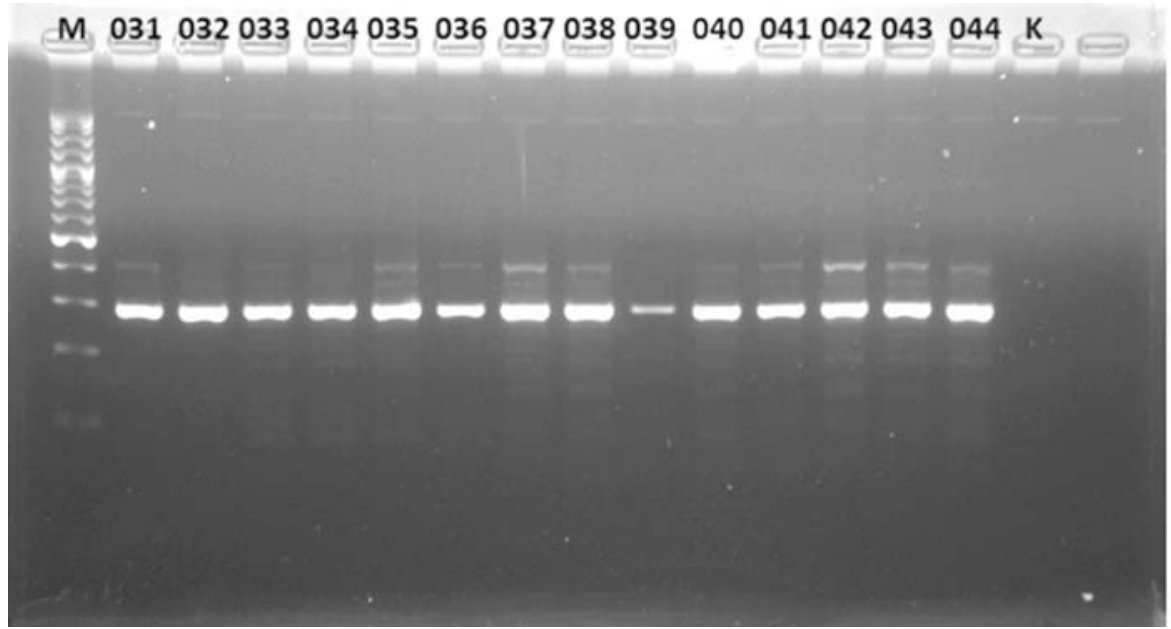

$288 \mathrm{bp}$

Gambar 1. Hasil PCR gen FPN1 -1355 sampel no. 31, 32, 33, 34, 35, 36, 37, 38, 39, 40, 41, 42, 43, 44. Keterangan: $K K=$ kontrol; $M=$ marker; Panjang produk PCR 288bp

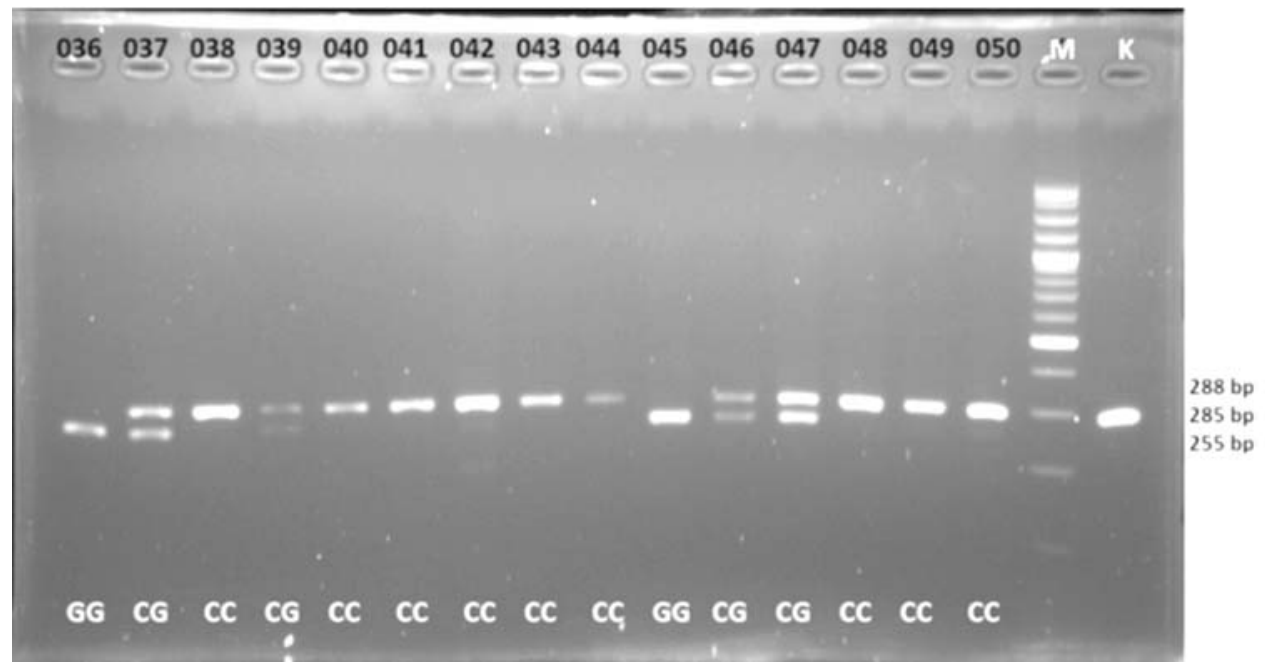

Gambar 2. Hasil PCR-RFLP FPN1 -1355 G/C sampel no. 36, 37, 38, 39, 40, 41, 42, 43, 44, 45, 46, 47, 48, 49, 50. Produk PCR didigesti dengan enzim Bfal. Genotip GG ditunjukkan pada band 255 dan 30 bp, GC 285, 255, dan 30 bp, sedangkan CC pada 285 bp. Keterangan: $\mathrm{KK}=$ kontrol; $\mathrm{M}$ = marker; $\mathrm{GG}$ = wild type; $C G=$ heterozigot mutant; $C C=$ homozigot mutant 
Tabel 3. Distribusi genotip (CC, CG, GG) dan alel (C,G) promoter FPN1 posisi -1355 pada subjek ADB dan bukan ADB

\begin{tabular}{|c|c|c|c|c|c|}
\hline \multicolumn{2}{|c|}{ Variabel } & ADB & Bukan ADB & p & OR (Cl 95\%) \\
\hline \multirow[t]{4}{*}{ Genotip } & CC & $3(60 \%)$ & $10(47,6 \%)$ & 0,814 & 0,814 \\
\hline & CG & $2(40 \%)$ & $10(47,6 \%)$ & & \\
\hline & GG & $0(0 \%)$ & $1(4,8 \%)$ & & \\
\hline & $\mathrm{GC}+\mathrm{CC}$ & $5(100 \%)$ & $20(95,2 \%)$ & 1,000 & $0,800(0,658 ; 0,973)$ \\
\hline \multirow[t]{2}{*}{ Alel } & C & $8(80 \%)$ & $30(71,4 \%)$ & 0,710 & $1,600(0,296 ; 8,653)$ \\
\hline & $G$ & $2(20 \%)$ & $12(28.6 \%)$ & & \\
\hline
\end{tabular}

Tabel 4. Perbedaan rerata kadar $\mathrm{Hb}$, indeks eritrosit, sTfR, dan ferritin antar kelompok genotip pada total subjek ibu hamil anemia

\begin{tabular}{|c|c|c|c|c|c|}
\hline \multirow{3}{*}{ Variabel } & \multicolumn{4}{|c|}{ Nilai (rerata $\pm S D)$} & \multirow{3}{*}{$\mathbf{p}$} \\
\hline & \multicolumn{2}{|r|}{ ADB $(n=5)$} & \multicolumn{2}{|c|}{ Bukan ADB $(\mathrm{n}=21)$} & \\
\hline & Wild type $(\mathrm{n}=0)$ & Polimorfisme $(n=5)$ & Wild type $(\mathrm{n}=1)$ & Polimorfisme $(n=20)$ & \\
\hline Kadar Hb (g/dL) & & $10,200 \pm 0,579$ & 10,800 & $10,350 \pm 0,358$ & $0,401^{*}$ \\
\hline Kadar MCV (fL) & & $69,940 \pm 4,475$ & 97,500 & $88,060 \pm 4,157$ & $0,000^{*}$ \\
\hline Kadar MCH (pg/sel) & & $22,200 \pm 2,019$ & 33,200 & $29,195 \pm 1,742$ & $0,000^{*}$ \\
\hline Kadar MCHC (g/dL) & & $31,720 \pm 0,920$ & 34,100 & $33,150 \pm 1,406$ & $0,088^{*}$ \\
\hline Kadar sTfR (nmol/L) & & $30,905 \pm 8,912$ & 26,294 & $\begin{array}{c}18,651 \pm 6,729 \\
(n=18)\end{array}$ & $0,009^{*}$ \\
\hline Kadar ferritin & & $196,167 \pm 1,17$ & 23,250 & $66,048 \pm 1,17$ & $0,045^{*}$ \\
\hline
\end{tabular}

Keterangan: * one way ANOVA; $\mathrm{ADB}=$ anemia defisiensi besi; $\mathrm{SD}=$ standar deviasi; $\mathrm{Hb}=$ hemoglobin; $\mathrm{MCV}=$ mean corpuscular volume; $\mathrm{MCH}$ = mean corpuscular hemoglobin; $\mathrm{MCHC}=$ mean corpuscular hemoglobin concentration; sTfR = soluble transferrin receptor

defisiensi besi (bukan ADB) berdasarkan kadar Hb kurang dari $11 \mathrm{~g} / \mathrm{dL}$, MCV kurang dari $80 \mathrm{fL}$, dan $\mathrm{MCH}$ kurang dari 26 pg (11) yang tampak pada Tabel 2.

Pemeriksaan genotip subjek dilakukan dengan metode PCR-RFLP. Produk PCR gen FPN1 -1355 yang dihasilkan memiliki ukuran 392 bp (Gambar 1), yang selanjutnya dipotong dengan enzim Bfal. Alel C (varian) akan berukuran 285 bp sedangkan alel G (wild type) berukuran 255 dan 30bp (Gambar 2).

Pada studi ini, lima ibu hamil kelompok ADB seluruhnya memiliki genotip $\mathrm{GC}+\mathrm{CC}$ atau membawa alel C. Sementara itu, genotip GG tidak ditemukan pada subjek ADB sehingga pada studi ini alel $C$ dianggap varian meskipun frekuensinya lebih tinggi daripada alel G. Perhitungan odds ratio (OR) alel $C$ untuk kejadian $A D B$ sebesar 1,600 (95\% Cl: 0,296-8,653) (Tabel 3).

Hubungan antara alel $\mathrm{C}$ dengan rerata kadar $\mathrm{Hb}$, $\mathrm{MCV}, \mathrm{MCH}, \mathrm{MCHC}$ menunjukkan kadar lebih rendah antar kelompok subjek ADB dan anemia bukan ADB (Tabel 4), meskipun kadar $\mathrm{Hb}$ tidak berbeda bermakna $(p=0,401)$. Diketahui bahwa kadar $\mathrm{Hb}$ bukan merupakan indikator spesifik ADB. Rerata kadar sTfR pada subjek ADB dengan genotip yang membawa alel $\mathrm{C}$ (polimorfisme) lebih tinggi bermakna dibandingkan non ADB baik wild type (GG) maupun polimorfisme (CG/CC) $(p<0,05)$. Demikian juga rerata kadar ferritin yang lebih tinggi pada subjek yang membawa alel $\mathrm{C}$ dibandingkan subjek dengan alel $\mathbf{G}$ $(p=0,045)$, meskipun pada subjek ADB lebih rendah daripada subjek anemia bukan karena defisiensi besi.
Pemeriksaan kadar ferritin selanjutnya menggambarkan status besi tubuh. Rerata kadar ferritin subjek adalah 48,5 $\pm 46,1 \mathrm{ng} / \mathrm{mL}$ dengan kadar minimal 1,2 $\mathrm{ng} / \mathrm{mL}$ dan maksimal $197,9 \mathrm{ng} / \mathrm{mL}$. Dua puluh enam subjek $(63,4 \%)$ diantaranya memiliki kadar ferritin serum normal $(12-120 \mathrm{ng} / \mathrm{mL}), 9$ subjek $(22 \%)$ rendah $(<12 \mathrm{ng} / \mathrm{mL})$, dan 6 subjek $(14,6 \%)$ tinggi (>120 ng/mL). Hal ini menunjukkan bahwa sebagian besar subjek memiliki simpanan besi yang cukup dengan rerata yang baik.

\section{BAHASAN}

Gen FPN1 memiliki regio promoter atau tempat pengikatan faktor transkripsi (TFBs) yang berperan dalam ekspresi gen pada level transkripsional. Diketahui bahwa untranslated region (5'-UTR) FPN1 terlibat dalam homeostasis besi dengan regulasi iron-responsive element (IRE). Secara post-transkripsional, homeostasis besi dikontrol oleh iron-regulatory protein (IRP1 dan IRP2). Sementara itu, IRPs adalah RNA terikat protein di sitosol. Level besi dalam sel akan meregulasi beberapa protein yang terlibat dalam homeostasis besi. Iron-regulatory protein yaitu IRP1 dan IRP2 mengikat IRE pada 5' atau 3' UTR dari mRNA yang mengkode protein tersebut. IRPs dan IRE bekerja dalam menghubungkan sense dan merespon untuk mengubah level besi dalam sel. Tergantung di mana IRE terletak, ikatan IRP akan memberi efek berbeda pada sintesis protein. Transversi nukleotida G ke C pada posisi 1355 upstream dari inisiasi ATG 
(5’UTR-1355G/C) (refSNP ID: rs3811621) tersebut pada penelitian sebelumnya ditemukan $8(34,8 \%)$ homozigot dan $13(56,5 \%)$ heterozigot pada kelompok pasien porphyria cutanea tarda (PCT) dengan gangguan metabolisme besi (12). Data HapMap pada populasi Asia menunjukkan bahwa frekuensi alel polimorfik 5'UTR-FPN1-1355 G/C (rs3811621) sebesar 10,4-16,2\%. Sementara itu, pada penelitian lainnya diperoleh frekuensi polimorfisme 5'UTR$1355 \mathrm{C} / \mathrm{G}$ sebesar $64 \%$ heterozigot pada kelompok pasien PCT dengan gangguan metabolisme besi (7).

Secara normal, besi seluler akan dilepaskan dari sel retikulosit, enterosit duodenum, plasenta, hepatosit, dan makrofag lien melalui transporter ferroportin. Makrofag akan melepaskan besi dengan katabolisme eritrosit yang sudah tua. Sementara itu, sumsum tulang akan menangkap besi sirkulasi untuk eritropoiesis. Kondisi ini berlangsung terus menerus untuk mempertahankan homeostasis besi. Hepcidin sebagai pengatur ekspresi ferroportin distimulasi oleh kadar besi, aktivitas eritropoiesis, dan inflamasi $(4,13,14)$. Sementara itu, pada polimorfisme FPN1 dapat berakibat pada perubahan ekspresi ferroportin dan peningkatan sensitivitas ikatan terhadap hepcidin. Ikatan hepcidin pada sisi ikatnya di permukaan ferroportin menyebabkan fosforilasi, internalisasi, dan degradasi ferroportin oleh lisosom (15).

Pada studi ini, semua subjek ibu hamil ADB memiliki genotip $\mathrm{GC}+\mathrm{CC}$ atau membawa alel $\mathrm{C}$. Perhitungan OR alel $C$ untuk kejadian ADB terhitung sebesar 1,600 $(95 \% \mathrm{Cl}: 0,296-8,653)$ sehingga dapat dikatakan alel $\mathrm{C}$ merupakan faktor risiko ADB. Subjek dengan alel $\mathrm{C}$ memiliki risiko 1,6 kali atau memiliki probabilitas sebesar $61,5 \%$ untuk mengalami ADB dibandingkan subjek dengan alel G. Alel C pada promoter gen FPN1 -1355 5'UTR diketahui dapat meningkatkan translasi gen FPN1 sehingga ekspresi ferroportin meningkat. Iron regulatory element (IRE) yang berlokasi di 5'UTR gen FPN1 fungsional pada hepar, usus, dan sel line monosit memungkinkan untuk merespon manipulasi besi secara bebas dari elemen promoter lainnya. Penelitian pada manusia menunjukkan mutasi di FPN1-IRE dapat menyebabkan deregulasi ekspor besi dari sel dan menyebabkan perubahan penyakit, atau sebagai faktor modifikasi ekspresi fenotip penyakit lainnya, seperti hemochromatosis dan ADB (16).

Alel C pada polimorfisme FPN1 -1355 G/C menyebabkan faktor transkripsi FOXC1 terikat pada IRE 5 sehingga terjadi peningkatan translasi gen FPN1 (12). Peningkatan ekspresi ferroportin menyebabkan ekspor besi juga meningkat. Ekspor besi yang meningkat menyebabkan penurunan konsentrasi ferritin dan peningkatan kebutuhan besi seluler sehingga terjadi peningkatan ekspresi sTfR. Defisiensi besi menyebabkan eritropoesis terganggu yang ditandai dengan penurunan kadar $\mathrm{Hb}, \mathrm{MCV}, \mathrm{MCH}$, dan MCHC. Hasil yang tidak menunjukkan perbedaan bermakna pada frekuensi alel antar kelompok $\mathrm{ADB}$ dan anemia bukan $\mathrm{ADB}$ kemungkinan disebabkan oleh pengelompokan subjek menjadi kelompok ADB berdasarkan kadar $\mathrm{Hb}$ dan indeks eritrosit yang diketahui hanya memiliki sensitivitas dan spesifisitas rendah.

Perbedaan bermakna hanya ditunjukkan pada kadar indeks eritrosit MCV, MCH, dan STfR antar kelompok genotip pada ibu hamil ADB dan anemia bukan ADB $(p<0,05)$. Diketahui bahwa indeks eritrosit dan sTfR memiliki sensitivitas dan spesifisitas lebih tinggi dibandingkan kadar $\mathrm{Hb}$ untuk diagnosis ADB (17-19). Meskipun demikian, kadar $\mathrm{Hb}, \mathrm{MCV}, \mathrm{MCH}, \mathrm{MCHC}$ yang rendah, dan sTfR yang tinggi pada subjek ibu hamil dengan genotip CG dan CC sejalan dengan nilai $O R$ alel C terhadap kejadian ADB sebesar 1,600 sehingga alel $C$ merupakan faktor risiko kejadian ADB.

Penentuan alel $\mathrm{C}$ sebagai faktor risiko selanjutnya dikonfirmasi dengan kadar $\mathrm{Hb}$, indeks eritrosit, level serum STfR, dan ferritin untuk masing-masing genotip. Pemeriksaan 26 ibu hamil anemia menunjukkan hanya 5 yang anemia defisiensi besi $(\mathrm{MCV}<80 \mathrm{fl}, \mathrm{MCH}<26 \mathrm{pg} /$ sel, dan atau $\mathrm{MCHC}<31 \%$ ), artinya tidak semua subjek anemia adalah anemia defisiensi besi. Pada kondisi defisiensi besi, terdapat peningkatan porphyrin bebas di sel darah merah sehingga enzim yang membawa besi pada heme, ferrochelatase, dihambat. Sintesis protein $\mathrm{Hb}$ juga dihambat, tetapi kemungkinan terdapat inisiasi rantai residu. Ribonucleotide reductase (RR) adalah protein besi non heme yang umumnya paling sensitif terhadap defisiensi besi, yang menyebabkan penghambatan sintesis DNA. Hambatan RR oleh hydroxyurea menyebabkan anemia makrositik (hambatan sintesis DNA) dan bukan anemia mikrositik, sebagai gambaran ADB (20).

Pemeriksaan konfirmasi pada kadar ferritin subjek menunjukkan bahwa sebagian besar subjek memiliki simpanan besi yang cukup dengan rerata yang baik. Meskipun demikian, ferritin merupakan protein fase akut dan merupakan indikator simpanan besi yang tidak spesifik pada pasien dengan infeksi, inflamasi, kanker, penyakit liver, dan aktivitas berlebih. Apabila terdapat kondisi seperti yang disebutkan, kadar ferritin akan meningkat dan tidak lagi dapat mengukur penyimpanan besi secara profesional karena proses inflamasi akan menghambat mobilisasi besi dari tempat penyimpanannya di sel retikuloendotelial (20-22).

Hasil analisis menunjukkan bahwa kadar $\mathrm{Hb}$ dan ferritin serum menunjukkan korelasi negatif dengan kekuatan korelasi sangat lemah $(r=-0,064 ; p=0,689)$. Hasil korelasi negatif menunjukkan apabila terjadi penurunan $\mathrm{Hb}$, maka terjadi peningkatan ferritin, vice versa. Pada penelitian ini subjek yang menderita infeksi, inflamasi, kanker, maupun penyakit liver tidak teridentifikasi saat proses pengambilan sampel sehingga tingginya kadar ferritin serum dapat disebabkan hal-hal tersebut. 
Ferroportin diregulasi secara pasca-translasional oleh hormon peptida hepcidin. Hepcidin sebagai regulator besi utama yang meregulasi pelepasan besi secara inhibisional dengan berikatan pada ferroportin dan mendorong internalisasi serta degradasi protein $(3,23)$. Pada kondisi inflamasi, sel kupffer pada liver akan melepaskan interleukin-6 (IL-6) yang dapat meningkatkan aktivitas hepcidin. Hal ini menjelaskan terjadinya blokade retikuloendotelial yaitu simpanan besi tidak bisa dilepaskan sehingga ferritin serum tinggi namun saturasi transferin rendah (23). Begitu banyaknya protein yang terlibat dalam homeostasis besi, menjadi penting untuk menjelaskan lebih lanjut patogenesis anemia defisiensi besi pada ibu hamil. Pada penelitian ini, baik status inflamasi melalui beberapa sitokin inflamasi, kadar ferroportin, serta hepcidin serum tidak diukur sehingga tidak terdeteksi dan dapat mempengaruhi hasil penelitian.

Penelitian ini menjelaskan bahwa adanya variasi gen FPN1 -1355 G/C pada ibu hamil tidak meningkatkan risiko anemia secara umum pada ibu hamil, akan tetapi dapat meningkatkan risiko secara spesifik pada anemia defisiensi besi ibu hamil yang ditandai dengan rendahnya $\mathrm{Hb}$ dan indeks eritrosit, serta meningkatnya kadar sTfR. Namun, defisiensi besi yang dimaksud adalah kekurangan besi untuk eritropoiesis atau adanya gangguan transportasi besi, meskipun simpanan besi dalam sel (ferritin) cukup. Hal ini sesuai dengan hasil penelitian ini bahwa hubungan kadar $\mathrm{Hb}$ dan ferritin menghasilkan nilai korelasi negatif sehingga gangguan eritropoiesis yang terjadi bukan disebabkan oleh kurangnya asupan besi melainkan karena gangguan ekspor besi.

Ditemukannya prevalensi anemia lainnya pada ibu hamil yang lebih tinggi (80\%) dibandingkan kejadian ADB $(20 \%)$ pada studi ini menunjukkan bahwa patogenesis anemia kehamilan lebih kompleks daripada ineffective erythropoiesis yang disebabkan oleh defisiensi besi atau folat, serta terjadi peningkatan proinflamatori sitokin. Kondisi kehamilan dapat memperparah stres oksidatif yang akan meningkatkan sitokin proinflamasi interleukin-6 (IL-6), interleukin-1 (IL-1), interferon gamma (IF- $\alpha$ ), dan tumor necrosis factor alpha (TNF- $\alpha$ ). Kondisi tersebut menyebabkan pengaktifan jalur janus kinase/signal transducer and activator of transcription (JAK-STAT) sehingga terjadi peningkatan sintesis hepcidin. Hepcidin akan menghambat pelepasan besi dari sistem makrophageal, akibatnya terjadi hipoferemia dan pembatasan besi untuk eritropoiesis. Hal ini menjelaskan adanya anemia inflamasi dan bukan anemia defisiensi besi (24-27). Dengan demikian, penting sekali dilakukan evaluasi kembali terhadap program suplementasi besi pada setiap ibu hamil karena pemberian besi pada ibu hamil yang tidak mengalami anemia defisiensi besi justru dapat menyebabkan resistensi insulin dan peningkatan sindrom metabolik $(8,9)$.

\section{SIMPULAN DAN SARAN}

Polimorfisme promoter gen ferroportin -1355 G/C bukan merupakan faktor risiko terjadinya anemia kehamilan secara umum, melainkan sebagai faktor risiko anemia defisiensi besi pada ibu hamil pada studi ini. Hal ini dibuktikan dengan parameter $\mathrm{Hb}$ dan indeks eritrosit yang rendah serta kadar sTfR yang tinggi pada ibu hamil yang membawa alel varian $\mathrm{C}$. Varian ini berpengaruh pada gangguan ekspor besi yang dapat meningkatkan risiko ADB, bukan pada gangguan simpanan besi. Hal ini disimpulkan dari tidak terdapatnya hubungan bermakna antara kadar $\mathrm{Hb}$ dengan kadar ferritin serum ibu hamil pada studi ini.

\section{UCAPAN TERIMA KASIH}

Penulis sangat berterima kasih kepada Risbin IPTEKDOK 2012 dari Kementrian kesehatan RI dan 'Dana Masyarakat' dari Universitas Gadjah Mada.

\section{RUJUKAN}

1. World Health Organization. Worldwide prevalence of anaemia 1993-2005. Geneva: WHO global database on anaemia; 2008.

2. Kementrian Kesehatan RI. Profil kesehatan Indonesia. Pusat data dan informasi. Jakarta: Kementerian Kesehatan RI; 2011.

3. Knutson MD. Iron-sensing proteins that regulate hepcidin and enteric iron absorption. Annu Rev Nutr 2010;30:149-71.

4. Nemeth E. Targeting the hepcidin-ferroportin axis in the diagnosis and treatment of anemias. Adv Hematol 2010;2010:750643.

5. Kalaivani K. Prevalence \& consequences of anaemia in pregnancy. Indian J Med Res 2009;130(5):627-63.

6. Farmawati A, Istiqomah I, Dewi VS, Umarghanies SS. Anemia defisiensi besi pada ibu hamil: analisis polimorfisme gen ferroportin Q248H dan asupan nutrisi. Laporan Dana Masyarakat. Yogyakarta: Fakultas Kedokteran Universitas Gadjah Mada; 2012.

7. Panton N. Mutation analysis of four genes implicated in iron homeostasis in porphyria cutanea tarda (PCT) patients [Thesis]. Stellenbosch, South Africa: University of Stellenbosch; 2008.

8. Bo S, Menato G, Villois P, Gambino R, Cassedar M, Cotrino I, Cavallo-Perin P. Iron supplementation and gestational diabetes in midpregnancy. Am J Obstet Gynecol 2009;201(2):158.e1-6

9. Bowers K, Yeung E, Williams MA, Qi L, Tobias DK, Hu FB, Zhang C. A prospective study of prepregnancy dietary iron intake and risk for gestational diabetes mellitus. Diabetes Care 2011;34(7):1557-63. 
10. Rivers CA, Barton JC, Gordeuk VR, Acton RT, Speechley MR, Snively BM, Leiendecker-Foster C, Press RD, Adams PC, McLaren GD, Dawkins FW, McLaren CE, Reboussin, DM. Association of ferroportin Q248H polymorphism with elevated levels of serum ferritin in African Americans in the Hemochromatosis and Iron Overload Screening (HEIRS) Study. Blood Cells Mol Dis 2007;38(3):247-52.

11. Departemen Kesehatan RI. Laporan nasional riset kesehatan dasar 2005. Jakarta: Departemen Kesehatan RI, 2005.

12. Hallendorff MA. Ironing out haemochromatosis: a study of an Indian family [Thesis]. Stellenbosch, South Africa: University of Stellenbosch; 2008.

13. Pietrangelo $A$. The ferroportin disease. Blood Cells Mol Dis 2004;32(1):131-8.

14. Cui $Y, W u Q$, Zhou $Y$. Iron-refractory iron deficiency anemia: new molecular mechanisms. Kidney Int 2009;76(11):1137-41.

15. Crichton RR. Iron metabolism-from molecular mechanism to clinical consequences. 3rd ed. UK: John Willey and Sons; 2009.

16. Lymboussaki A, Pignatti E, Montosi G, Garuti C, Haile DJ, Pietrangelo $A$. The role of the iron responsive element in the control of ferroportin1/IREG1/MTP1 gene expression. J Hepatol 2003;39(5):710-5.

17. Akesson A, Bjellerup P, Berglund M, Bremme K, Vahter M. Serum transferrin receptor: a specific marker of iron deficiency in pregnancy. Am J Clin Nutr 1998;68(6):1241-6.

18. Wians FH, Urban JE, Keffer JH, Kroft SH. Discriminating between iron deficiency anemia and anemia of chronic disease using traditional indices of iron status vs transferrin receptor concentration. Am J Clin Pathol 2001;115(1):112-8.

19. Lopez-Sierra M, Calderon S, Gomez J, Pilleux L. Prevalence of anaemia and evaluation of transferrin receptor (sTfR) in the diagnosis of iron deficiency in the hospitalized elderly patients: anaemia clinical studies in Chile. Anemia 2012;2012:646201. doi: 10.1155/2012/646201.

20. Kell DB. Iron behaving badly: inappropriate iron chelation as a major contributor to the aetiology of vascular and other progressive inflammatory and degenerative diseases. BMC Med Genomics 2009;2(2).

21. Lwanga JB. Serum ferritin levels and birth outcomes for rural pregnant women in Tororo District. Uganda: Child Health and Development Centre Makarere University; 2008.

22. Van der Broek NR, Letsky EA, White SA, Shenkin A. Iron status in pregnant women: wich measurements are valid?. Br J Haematol 1998;103(3):817-24.

23. Wish JB. Assessing iron status: beyond serum ferritin and transferrin saturation. Clin J Am Soc Nephrol 2006;1(Suppl 1):S4-8.

24. Mackenzie EL, Iwasaki K, Tsuji Y. Intracellular iron transport and storage: from molecular mechanism to health implication. Antiox Red Sign 2008;10(6):9971030.

25. Ferrucci L, Semba RD, Guralnik JM, Ershler WB, Bandinelli S, Patel KV, Sun K, Woodman RC, Andrews NC, Cotter RJ, Ganz T, Nemeth E, Longo DL. Proinflammatory state, hepcidin, and anemia in older persons. Blood 2010;115(18):3810-6.

26. Ganz T, Olbina G, Girelli D, Nemeth E, Westerman $M$. Immunoassay for human serum hepcidin. Blood 2008;112(10):4292-7.

27. Jason J, Archibald LK, Nyanyanwu OC, Bell M, Jensen RJ, Gunter E, Buchanan I, Larned J, Kazembe PN, Dobbie $\mathrm{H}$, Jarvis WR. The effects of iron deficiency on lymphocyte cytokine production and activation: preservation of hepatic iron but not at all cost. Clin Exp Immunol 2001;126(3):466-73. 